\title{
Cultural traits and productive transformation: Colombia in international perspective ${ }^{*}$
}

\author{
Fabián Garzón-Cuervo** \\ University of Lisbon (ISEG) \\ fabiangarzon@phd.iseg.ulisboa.pt
}

Recibido: 13 de marzo de 2019

Revisado: 24 de marzo de 2019

Aprobado: 4 de junio de 2019

* Cómo citar este artículo: Garzón-Cuervo, F. (2019). Cultural traits and productive transformation: Colombia in international perspective. Revista CIFE: Lecturas de Economía Social, 21(35), 105-139. DOI: https://doi. org/10.15332/22484914.5372

* Economist, Universidad Nacional de Colombia. Ph.D. Candidate in Development Studies at the Lisbon School of Economics and Management (ISEG) of the University of Lisbon. ORCID: 0000-0003-0771-6776 


\section{Abstract}

Drawing from the consideration of cultural values as an explanatory factor of economic development, this article correlates the cultural traits reported by Hofstede's Cultural Dimension model with the results in terms of industrialization for Colombia and selected cultural clusters. By contrasting industrialization-oriented policy choices with the evolution of export composition and industrial competitiveness indicators, we conclude that guided by a short-term, materialistic, nepotistic, and intolerant to uncertainty orientation, Colombian economic authorities and elites have helped in the prolongation of an underdeveloped industrial structure by favoring closed groups through extractive institutions, while Asia, instead of adopting 'western values', has drawn upon a long-term orientation to implement risky but sound, coordinated, and convergent social and economic policies in order to industrialize.

Keywords: Culture, Industrialization, Colombia, Asia, Hofstede.

Classification JeL: O10, O14, O25, O54, O57

\section{Resumen}

Partiendo de la consideración de los valores culturales como un factor explicativo del desarrollo económico, este artículo relaciona los rasgos culturales reportados por el Modelo de Dimensiones Culturales de Hofstede con los resultados en términos de industrialización para Colombia y grupos culturales seleccionados. A través del contraste de las preferencias en términos de políticas orientadas a la industrialización se concluye que, guiadas por una orientación cortoplacista, materialista, nepotista e intolerante a la incertidumbre, las autoridades y las élites económicas colombianas han ayudado en la prolongación de una estructura industrial subdesarrollada al favorecer a grupos cerrados a través de instituciones extractivas, mientras que Asia, en lugar de adoptar "valores occidentales" ha hecho uso de una orientación a largo plazo para implementar políticas económicas, aunque riesgosas, sólidas, coordinadas y convergentes en pro de su industrialización.

Palabras clave: cultura, industrialización, Colombia, Asia, Hofstede

Clasificación JeL: O10, O14, O25, O54, O57 


\section{Introduction}

Among the study of the factors that promote (or impede) socio-economic development and the policies to bolster (or redress) them, one is especially controversial: cultural traits. A growing strand of academics questions if culture is a decisive factor for economic development in spite of the inconclusiveness in the definitions of both 'culture' and 'economic development', but endorsed by general agreement on the idea that "culture can help explain how individuals think, interact with each other, and how they make economic decisions" (Lopez-Claros \& Perotti, 2014, p. 1).

Having productive transformation as one fundamental of economic development, we look at the predominant values in Colombia according to Hofstede's Cultural Dimension Theory and compare them with those identified as characteristic of both - technologically speaking - early developed regions (e.g. North America, Western Europe) and recently developing ones (e.g. South East Asia), by linking them to historical productive transformation trends, in order to pinpoint those national 'personality flaws' hampering, firstly, productive transformation, and ultimately, economic development in Colombia.

In the following pages we present (1) a brief outline of what we understand by cultural values, productive transformation, and the cultural hypothesis linking culture with economic development, (2) a summary of Hofstede's Cultural Dimensions Theory (HCD) and its scores for Colombia and significant cultural clusters, (3) the contrast of the Colombian productive transformation indicators compared to more recently industrialized cultural clusters, (4) our discussion and argument, and (5) our conclusions with brief suggestions for further research on the topic.

\section{Preliminary concepts}

\section{Culture}

Given the multiple connotations of the word, with special attributes depending on the area of knowledge in which it is used or the aspect under analysis (Sahuquillo, 1997), 'culture' will be understood here as an ethos, this is, "a mentality or attitude associated to a determined society or collective" (p. 175).

The locally-nuanced social organization systems built on - among other things - centralization of political and economic life into urban centers, institutions such as labor division and taxation, exhaustive law systems, record keeping, bureaucratic apparatuses, and technological progress such as new tools, artifacts, means of communication, productive systems, and trade (Braudel, 1994; Quigley, 1979) eventually have allowed some social groups to achieve better standards of living than others. A crucial question in the history of social and economic analysis is why. 
While is it true that culture can be a powerful social driver because values and beliefs shape individual and group behavior, its connection with economic performance is neither clearly defined nor measured. The direction of the causality is also contentious as the works of Granato, Inglehart, and Leblang (1996) on the effect of cultural values on economic development, and of Inglehart and Baker (2000) in the opposite direction show. Additionally - and perhaps even more controversial - a great deal of the mainstream scholars sponsor the belief that only the 'western' values promote socio-economic development based on the fact that the most economically successful and socially stable countries in the world - at least until some decades ago - are located in what is called 'the western world'. On the other hand, because of its complexity and the intangible character of its components, it is impossible to delimit 'culture' within clear spatial or temporal boundaries: one 'Latin American culture' or one 'Asian culture', for instance, seem rather arbitrary; even reducing the analysis to the national level and speaking of 'Colombian culture', 'German culture' or 'Chinese culture' can be hazardous, given the inland regional differences.

In spite of all that, and while we do not intend to fall into the trap of generalization, it must be accepted that under the umbrella of what Michaels (2011) calls 'master story', Colombians, Germans, Chinese or Israelis do share values, beliefs, myths, practices, artifacts and symbols mostly at intra- (with natives of the same country) but also at inter(with natives of different countries) national levels, and that some unique and unspoken marked cultural traits, specific to their location, kinship, heritage or social organization do have an effect in individual and group economic and political preferences, ultimately affecting institutional arrangements and economic performance, as remarked by Guiso, Sapienza, and Zingales (2006).

Aware of the aforementioned limitations, for the sake of the comparative exercise this work will presume, first, the existence of roughly defined, but analytically useful, 'cultural clusters' in which within each cluster (or country) an array of shared beliefs, values and customs prevail and steer social behavior towards a semi-unified economic conduct, ultimately leading clusters (or countries) to divergent degrees of living standards; and second, that the synergy between cultural traits and economic performance is a longstanding process for two fundamental reasons: customs are more or less changeless in the short-term and the social effects of economic development take long time to unfold and/or to be observable.

\section{Productive Transformation}

'Productive Transformation' is understood here as producing a wider and more sophisticated variety of goods (and services) that place society in a higher level of technical 
development. At first, as a key factor for "human [...] liberation from the vicissitudes of nature" (Peet \& Hartwick, 2009, p. 3), afterwards, because "industrial upgrading and diversification are essential [for the creation of] the preconditions for better jobs, poverty reduction and higher living standards" (Lin \& Treichel, 2014, p. 76), simply put, improvement of material capabilities and material living conditions.

However, industrialization can bring more than material well-being. Material security can also diminish the constraints on human choice through what Inglehart and Welzel call the 'emancipative effects of socioeconomic development' (2005, p. 24), and which they summarize as the enhancement of civil and political liberties, the promotion of diversified human aspirations and choice, the growth of human autonomy, and in general, human development (in the sense of progress), all resulting from the amalgamation of economic, political, social and cultural transformations conducive to social modernization. For its part, Edwards (2016) remarks the capacity of economic development to reinforce "the overall ability of people to lead lives that they find fruitful" (p. 8). Here, the implication of 'Productive Transformation' lies in its human empowerment capabilities.

The terms 'Economic Growth' and 'Economic Development' have enjoyed a prolonged status as preeminent concepts in social, political and economic analysis, and according to Brinkman (1995) they have been analytically considered both as synonyms (quoting Arndt) and as dissimilar: the former, as the quantitative increase of economic production - usually defined and measured in terms of Gross Domestic Product (GDP) - and the latter, as qualitative changes in economic structure and institutions (topics associated more recently with the conception of 'development'). He explains the conceptual correspondence by the association of "the quantitative statics of economic growth [...] with the processes of economic development" (p. 1171) or by the consideration of "Economic Growth' as a result of development (p. 1178).

Similarly to 'culture', the concept 'Economic Development' has exhibited diverse thematic and disciplinary transfigurations under phases we judge entitled to reflect the core matters under analysis, the key measurement indicators, the general goal, and/or the policy criterion to achieve it (e.g. 'Industrialization' in the 1950s, 'Modernization' in the 1960s, 'Structural Adjustment' in the 1980s, etc. $)^{1}$, for which here, its significance will be restricted to the inauguration of conditions favorable to social modernization and to the promotion of the human development process described above by Inglehart and Welzel, all, triggered by 'Productive Transformation'.

Since neither 'Economic Growth' nor 'Economic Development' encompass what we want to address here - being the first concept too limited and the second too broadthis article will be restricted to a limited set of indicators that allow us to correlate

1 Exhaustive descriptions on the conceptual evolution of 'Economic Development' can be found in Arndt (1981), Peet and Hartwick (2009) or Rist (2008). 
determined cultural traits with the inception and initial steps of economic transformation (read, productive transformation). We will concentrate on the industrial modernization sense of the transformation, manifested in an increased quantity, complexity and variety of exports of technologically upgraded production, say, not limited to basic commodities, and in the Industrial Competitiveness Index.

The focus solely on exports stems from extrapolating the view of Morrissey and Filatotchev (2000) regarding the ability of 'marginalized economies' to partake in the gains of trade globalization. According to them, the "ability to become integrated in global markets" (p. 3) is a result of the private prowess to increase efficiency and competitiveness when local firms are exposed to international competition added to public policies and institutional reforms intended to overcome the constraints generated by relative factor endowments or historical factors. The indicators, as well as further support for our choice will be elaborated in section 3.

\section{The Cultural Hypothesis}

Arguably, the first documented proposal connecting cultural traits and economic development can be found in Montesquieu's consideration of the people living within the tropics as "slothful, politically apathetic, timid of their masters, fearful of their gods, apt to superstition, and naturally cowardly", as opposed to the people living in temperate climates described as "more vigorous, more courageous, more frank, less suspicious, more polite, and cunning" (as quoted in Fowler, 2012, September 19), which for him constituted the reason for the poverty of the former and the affluence of the latter. From his reasoning, a deterministic proclivity - geographical in nature - to success or failure ensued, since, after all, laziness, superstition and political apathy sound like attitudes less likely to propel social and economic success than hard work, intellect and political participation.

But one of the most - if not the most - renowned theories correlating cultural traits with economic development has been proposed by Max Weber ([1930] 2005) who contended that the emergence of the Protestantism had a pivotal role in the evolution of capitalism-driven economic growth, notably through the introduction of the idea that 'economic success' was no longer in conflict with religiousness or spirituality. The new work ethic in turn promoted particular social and economic arrangements that resulted in dynamics that facilitated Protestants - considered as a culturally-homogeneous body - to attain swift economic and social development by altering their economic behavior following a cultural transformation ${ }^{2}$. On the basis of that interpretation of

2 Gil Villegas (2015) presents a detailed critique to the mainstream interpretation of Weber's works. He stresses that (a) Weber never said that Protestantism was chronologically or ideologically precursor of modern capitalism, which 
Weber's tenets, namely, that through the elimination of certain moral impediments for economic gain, resources were relocated into more productive or profitable activities, promoting the production of more diverse goods and services through a snowballing flow of capital, chaining and integrating more and more economic activities, and allowing more peoples to benefit from the proceeds of the productive system by opening opportunities for social mobility and constant self-improvement, we assume Weber's work on the matter, first, as a cultural hypothesis of economic development, and second, as a reference point in our analysis, because of the transfiguration of religion (a cultural aspect) as a powerful behavior influencer in the realm of business and work ethics (economic development aspects).

Weber's postulates (and the miscellaneous interpretations, derivations and controversies around them) provided the foundations for several subsequent conceptualizations and quantitative analyses of the nexuses between cultural traits and economic development $^{3}$, such as Inglehart and Welzel's Cultural Values Map, Kluckhorn and Strodtbeck's Cultural Value Orientations, the Schwartz Value Survey, or the Global Leadership and Organizational Behavior Effectiveness Research Program, out of which we adopt Hofstede's Cultural Dimensions (HCD), summarized next.

\section{Stylized facts regarding culture}

\section{Hofstede's Cultural Dimensions (HCD)}

Based on the analysis of the information collected by a multinational company that intended to analyze the values its employees embraced, Geert Hofstede identified four later expanded to six - cultural dimensions (HCD) which could allow to compare customs and work ethics around the world, and to establish correlation between country-specific cultural traits and, initially, organizational behavior, later, economic development and social cohesion. Each dimension establishes a continuum scale that reflects the prevalence of a determined value versus its 'direct opposite'. The dimensions, as presented in Hofstede, Hofstede, and Minkov (2010) are — and can be condensed - as follows:

\footnotetext{
is a simplification popularized by incorrect readings of his works; (b) the influence of the 'protestant ethic' in the 'spirit of capitalism' modified the trajectory of the dynamics of material interests which the development of capitalism already had since feudal times; (c) the material conditions for the development of capitalism existed long before Protestantism, but the 'sanctification of work' — in the form of vocation - was an additional contributing factor. Neither the only nor the most important one, but significant; and (d) he never published a book entitled "The Protestant Ethic and the Spirit of Capitalism", which is the result of the recompilation and translation of his works to English (pp. 26-33).

3 An expanded review of related literature can be found in Kapás (2017).
} 
Power Distance (PDI) represents the level of tolerance - especially of the less powerful groups - to hierarchization and arbitrariness in social institutions and organizations; Individualism (IDV) represents the level of acceptance and encouragement to individual-oriented actions and to some extent, weaker or stronger ties between individuals; Masculinity (MAS) represents the level of importance within interpersonal relations of determined values commonly associated as 'masculine' (assertiveness, toughness, and focus in material success) or 'feminine' (modesty, empathy, and nourishment); Uncertainty Avoidance (UAI) represents the discomfort felt by the members of the society when facing uncertain circumstances, as well as their degree of openness to novel situations and their preference to secure certainty under the current state of events; Long-Term Orientation (LTO) represents the level to which society foments actions oriented to achieve immediate results, opposed to the promotion of perseverance and sustained effort aimed to achieve future purposes via gradual development, and finally; Indulgence versus Restraint (IVR) represents the level of social tolerance towards expressions of self-gratification, privilege and self-expression.

The HCD model assigns scores from 1 (the lowest) to 120 (the highest) to each country in each dimension - noting that the score is relative to the dimension; thereby a low score in Power Distance (PDI) would reflect - in theory - a more egalitarian society, while a higher score would reflect a more hierarchical one. A low score in Individualism (IDV) would represent a more communalistic society, while a higher score would represent a more individualistic one. A low score in Masculinity (MAS) would represent a society in which immaterial welfare and caregiving are more important, while a higher score would represent a society in which material achievements are more important. A low score in Uncertainty Avoidance (UAI) would represent a society that feels more uncomfortable with uncertainty, while a higher score would represent a society more comfortable under uncertain situations. A low score in Long-Term Orientation (LTO) would reflect a society more concerned with short-term outcomes, while a higher score would reflect a more future-oriented one. Finally, a low score in Indulgence versus Restraint (IVR) would reflect a more proscriptive society, while a higher score would reflect a more permissive one.

The logic behind these dimensions is the contrast of two - more or less - dichotomous extremes (e.g. long-term versus short-term orientation) attempting to portrait the attitudes of members of society with regard to general aspects of life in either side of the spectrum, and how these attitudes will affect the social order or steer it into a certain transformative direction. The cultural dimensions relate to economic development because the latter "has for decades been considered primarily an economic and technical problem, a matter of transferring money and technology [forgetting that] nobody can develop a country but its own population" (Hofstede et al., 2010, p. 417). The implication is that values forge preferences and behavior, organizational culture, institutional arrangements, and ultimately socio-economic development. 
Before presenting the scores of the HCD, three caveats will be made. First, this work will not address all HCD's dimensions or compare Colombia with each and every country in the world, since it would entail a cumbersome operation. Given that our target is to analyze one particular segment of the process of economic development (read: productive transformation) that can only be estimated for long term periods, this work emphasizes Long-Term Orientation, yet addresses some of its links to other dimensions - according to us, related to productive transformation - when necessary. Second, while it is possible to argue that the scores exhibited in the HCD framework are the result - and not the cause - of the socio-economic conditions of the country in question at the moment of survey, and thus, all the values portrayed in the models reflect the aftermath of socioeconomic development rather than its preconditions, the global intention of the work will be still supported: to picture a plausible reciprocation between cultural values and productive transformation - and ultimately, economic development - in Colombia.

The cultural clusters presented are based on Jolley (2013) 'global villages' (see Annex 1), but adjusted to amend special cases such as Indonesia and Pakistan, allotted in the map to the Southeast Asian and Indic cultures respectively, yet populated by a Muslim religious majority; and Israel, located in the heart of the Muslim region in spite of being a predominantly Jewish state.

Figure 1: Hofstede's Cultural Dimensions for Colombia and 'Western clusters'
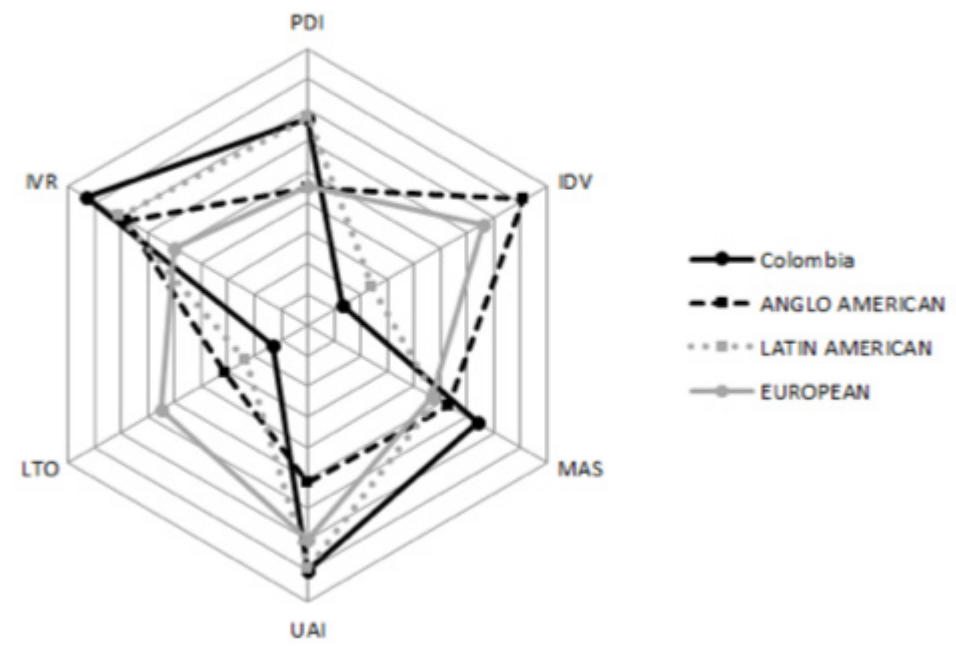

Source: Own construction with data from Hofstede (2015)

Figure 1 (above) compares Colombia with its historically or geographically closer cohorts": Latin America, North America and Europe. At first glance, some particularities stand out: (a) the higher tolerance of the Latin American and Colombian cultures to 
hierarchized societies compared to the Anglo American and the European clusters (both with identical scores); (b) the gap in terms of Individualism (IDV) between the Anglo American cluster, the European cluster and both the Latin American cluster - which excludes Colombia to avoid double registry - and Colombia, in spite of the common cultural traits resulted from colonialism; (c) the higher Masculinity (MAS) score of the Colombian society (the highest for the regions in question) which can be interpreted as a more marked proclivity to favor material achievement; and (d) the higher Long-Term Orientation (LTO) of the European cluster compared to the other groups under consideration, as well as the striking short-term orientation of Colombia, to which we will return later.

Figure 2 (below) compares Colombia with its historically or geographically farthest cohorts: Islamic, Sino and South East Asian countries. Here, it is possible to remark: (a) the relative homogeneity in terms of Power Distance (PDI) scores, displaying relative equivalence in terms of the acceptance to markedly hierarchical societies; (b) the low levels of Individualism (IDV) for all the segment, with Colombia as the least individualistic (or more communalistic) of them; (c) the similar levels of materialism - expressed in Masculinity (MAS) - of all clusters, having Colombian and the Sino cluster the exact same score; (d) the marked Uncertainty Avoidance (UAI) of Colombian society versus the cohort, and (e) the remarkable Long-Term Orientation (LTO) of the Sino cluster vis-à-vis the other groups under consideration, especially in comparison to the striking shortterm orientation of Colombia.

Figure 2: Hofstede's Cultural Dimensions for Colombia and 'Eastern clusters'
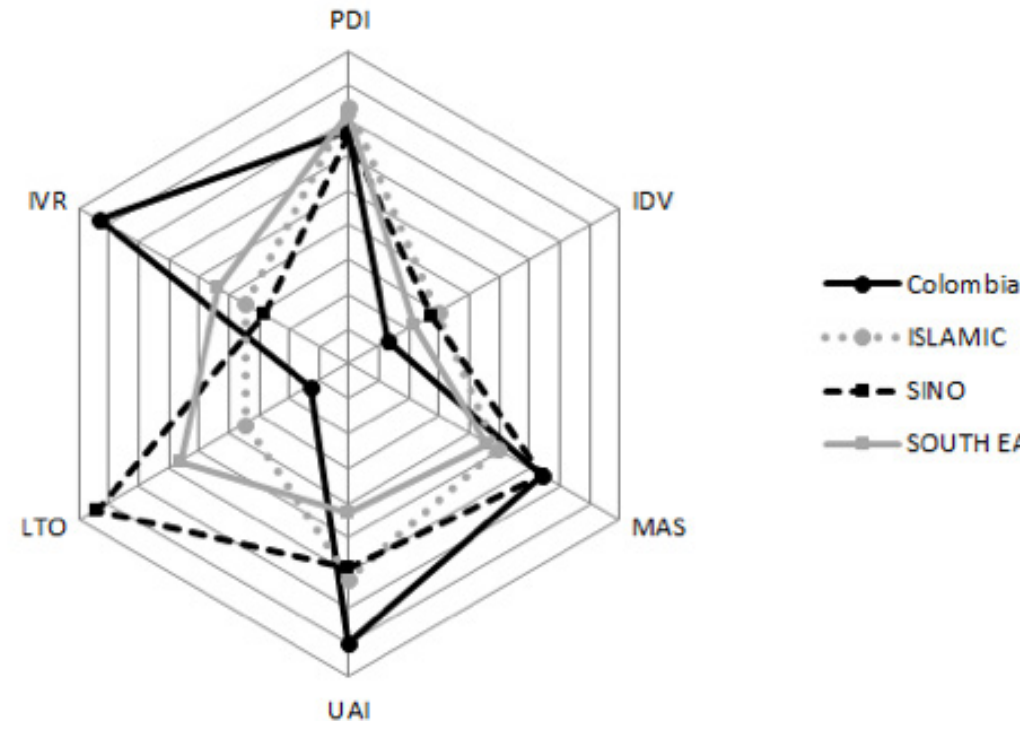

$* * *$ ISLAMIC

$-\pi-\operatorname{SINO}$

- SOUTH EAST ASIA

Source: Own construction with data from Hofstede (2015) 
When we compare cultural dimensions, this time according to income level ${ }^{5}$ (read, GNI per capita) (see Fig. 3 below), Colombia stands out with the lowest individualism (IDV) of the cohort, its higher emphasis on material achievements (MAS), its lower tolerance to uncertain situations (UAI), and specially with its conspicuous short-term orientation (low LTO).

Figure 3: Hofstede's Cultural Dimensions for Colombia and 'High Income clusters'

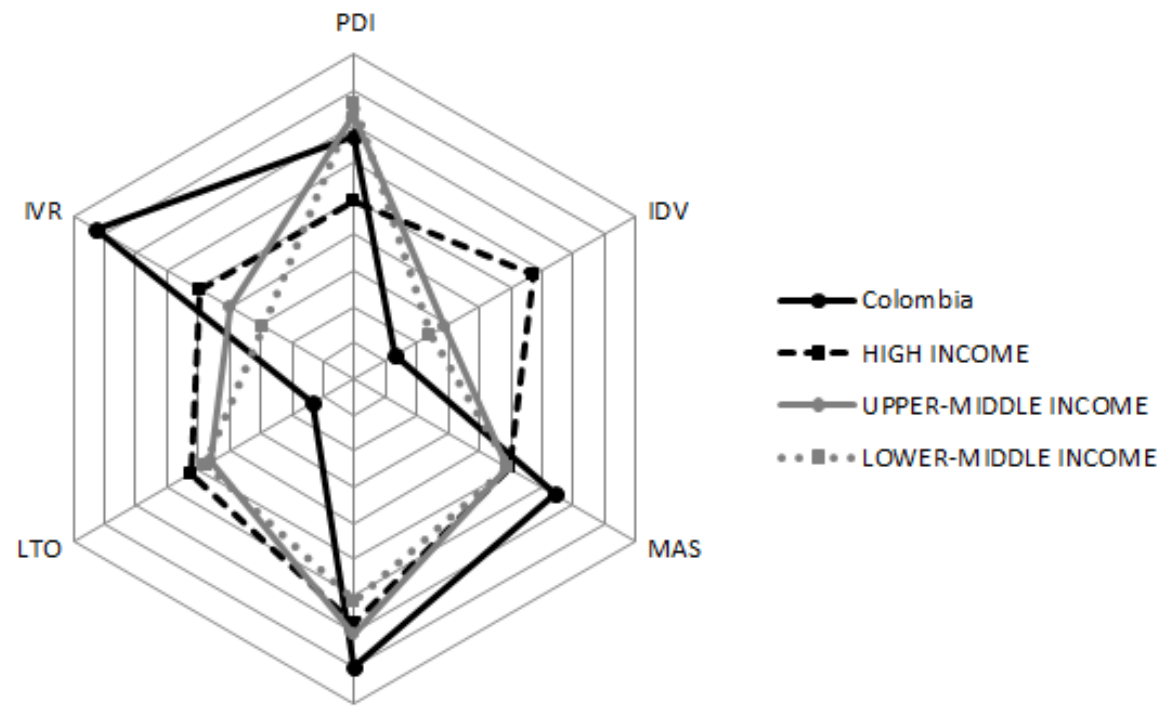

Source: Own construction with data from Hofstede (2015) and World Bank (2018b)

Lastly, when we compare the cultural dimensions pegged to a compound of income level and historically or geographically closeness (See Fig. 4, below), the outcome reinforces aforementioned findings: (a) the similar results regarding the acceptance to markedly hierarchical societies (PDI); (b) the higher levels of individualism displayed by the western cluster, with Colombia having the lowest of all; (c) the relatively coinciding degrees of Masculinity (MAS) and Uncertainty Avoidance (UAI) of all clusters, with Colombia scoring higher in the former, and (d) the salient long-term orientation of the eastern cluster versus the rest, emphasizing the characteristic short-term orientation of Colombian society.

5 The clusters presented in Fig. 3 merge highly culturally-dissimilar countries and regions given that the parameter of aggrupation is income. The high income group, for instance, includes the U.S., Japan and Israel, while the uppermiddle income group includes Brazil, Iran, South Africa and China. 
Figure 4: Hofstede's Cultural Dimensions for Colombia and 'High Income West and East clusters'
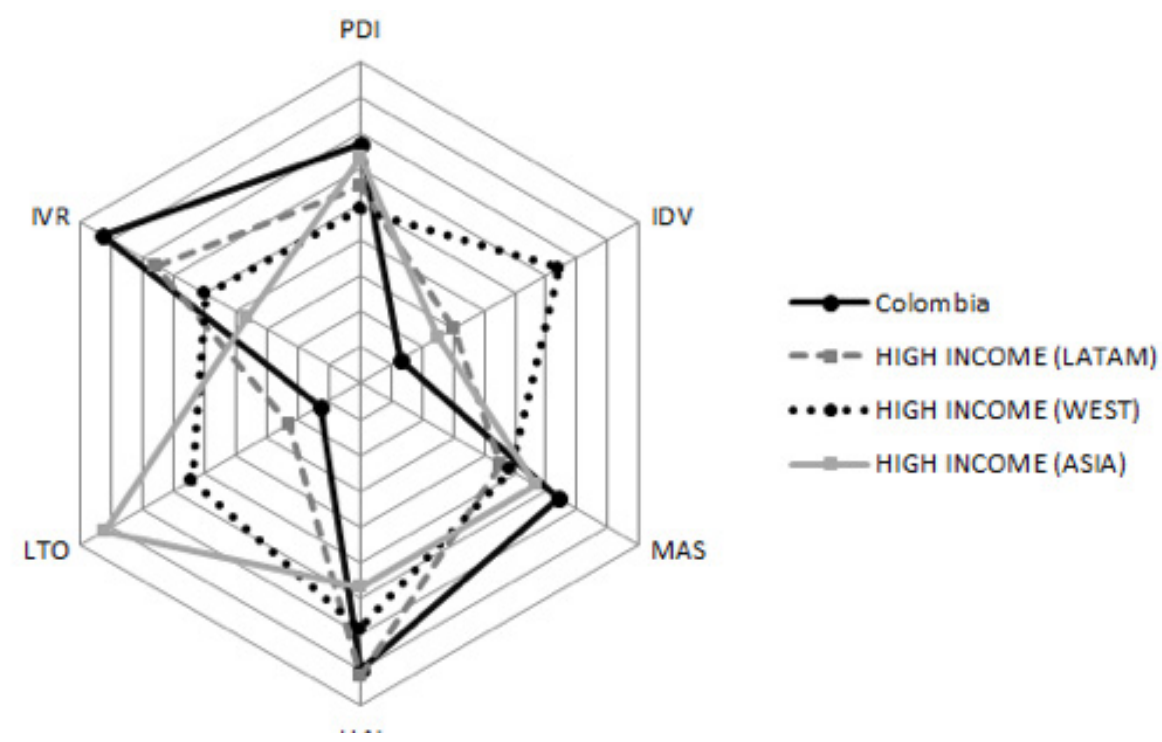

Source: Own construction with data from Hofstede (2015) and World Bank (2018)

All in all, compared to the selected cultural and income clusters, Colombia can be portrayed as having about the same levels in terms of Power Distance (PDI), and also an equivalent tolerance to a hierarchical society although with a much lower level of Individualism (IDV). A slightly higher level of Masculinity (MAS), which we interpret as a manifestation of a society inclined towards material achievements. Akin levels of tolerance to uncertain situations (UAI) although slightly higher, and astonishing low scores in terms of Long-Term Orientation (LTO), translatable into a short-term orientation. The reciprocity of these traits with the relative levels of 'Productive Transformation' - and ultimately economic development - achieved by Colombia will be discussed in section 4 .

\section{Productive transformation}

In order to contrast the 'Productive Transformation' of our subjects with their cultural traits, we will compare their results in terms of the variety of technologically upgraded exports, for which we follow the thesis presented by UNCTAD as "the virtues of manufacturing" (2016). The argument is that the expansion of manufactured production either for internal consumption or for export supports the building of Hirschmanian "backward" linkages (to source inputs for production) and "forward" linkages insofar as the produced goods are used in other economic activities" which help "to sustain a virtuous circle of growth and structural transformation" (p. 58). Besides, they note that 
The justification for the growth of manufacturing is not only economic, but also geopolitical and social. In today's globalized economy, a country that lacks a significant manufacturing sector may eventually face demand obstacles to growth and chronic balance-of-payments constraints, making it vulnerable to decisions of external financial agents and to policy conditions set by official creditors (p. 59).

When we analyze the export composition according to the stages of processing ${ }^{6}$ and averaged within the selected cultural clusters (See Graphic 1, below), we find that by 1990 raw materials (the least complex in terms of industrial transformation) represented more than half of Colombian exports, while capital goods (the most complex in terms of industrial transformation) represented less than $4 \%$ of them. Two facts do not come as surprise: that in the least developed or industrialized countries capital goods did not exceed $10 \%$ of their exports, and that early developed regions (i.e. North America, Western Europe) with longstanding established industrial systems display figures four times higher. On the other hand, the more recently developed ones (i.e. the Sino and South East Asia clusters) were already matching or exceeding the capital goods exports levels of the early developed regions, which the World Bank has since then labeled as the 'miracle of the High-performing Asian Economies'. A more detailed outline will be presented in the next section.

Graphic 1: Composition of Exports according to addedvalue in 1990 for selected cultural clusters

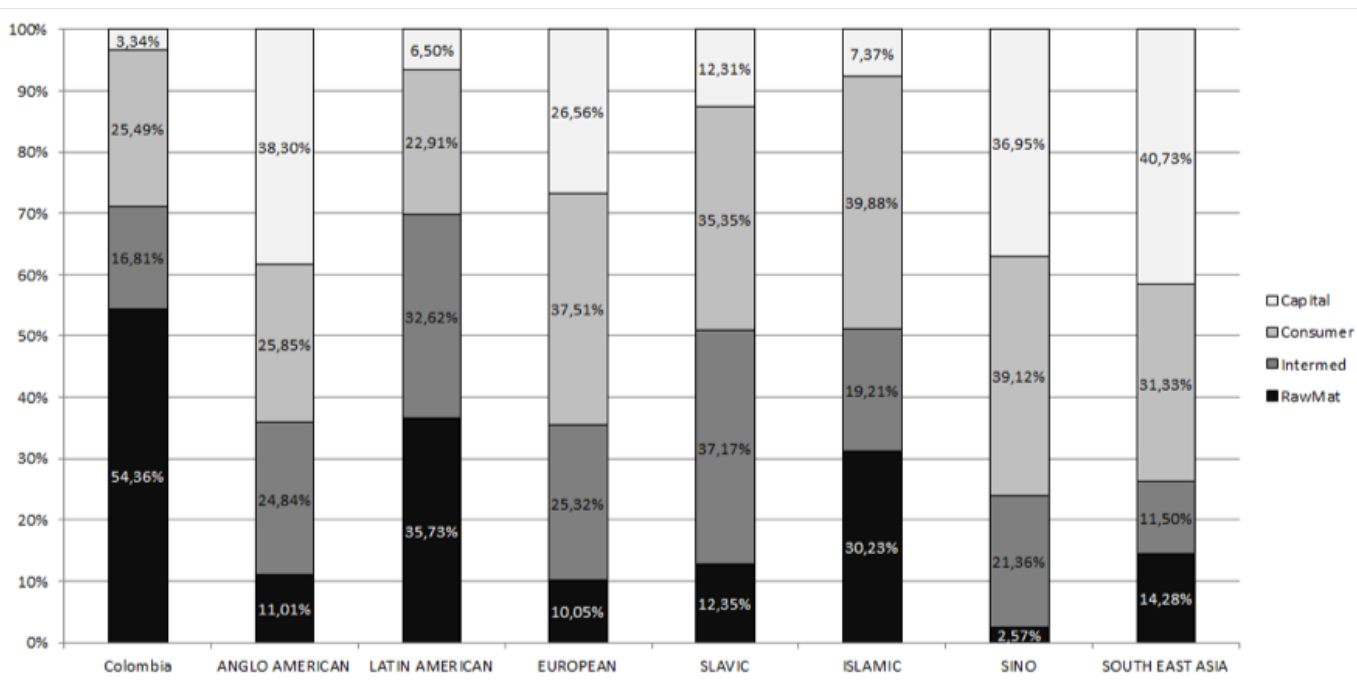

Source: Own construction with data from World Bank (2018a)

6 Following the Harmonized Commodity Description and Coding System (HS) 2007. 
As shown in the Graphic 2 (below), Colombia currently maintains its exports of capital, consumer, and intermediate goods in roughly the same levels of 1990, although it did increase - slightly - its raw materials exports. While it may be true that the other clusters under comparison have not drastically changed the composition of their exports either, in the same period Latin America has increased its capital goods exports in 50\%, and both the Sino and the South East Asia clusters have increased both their exports of more sophisticated products relative to their trade, and their industrial competitiveness (as shown in Graphic 3, below), even relegating North America (Anglo-American cluster) and Europe.

Graphic 2: Composition of Exports according to AddedValue Level in 2017 for selected cultural clusters

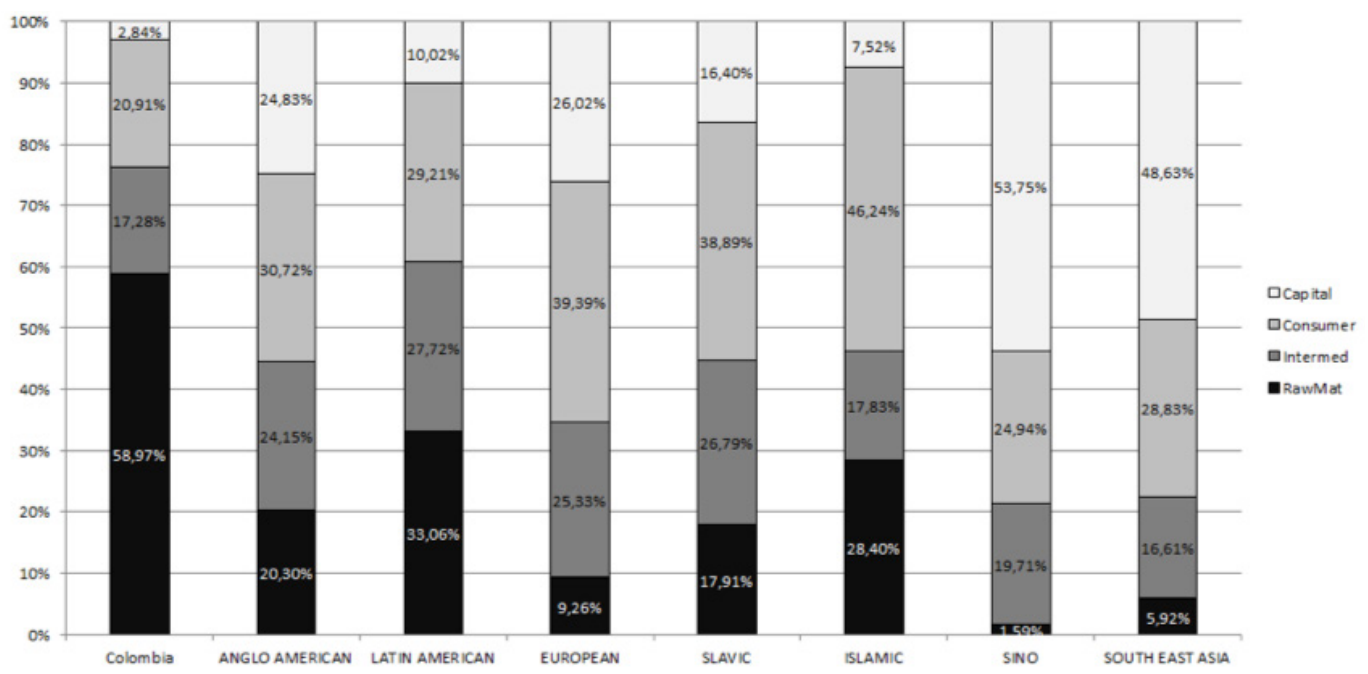

Source: Own construction with data from World Bank (2018a) 
Graphic 3: Competitive Industrial Performance Index in

1990 and 2017 for selected cultural clusters

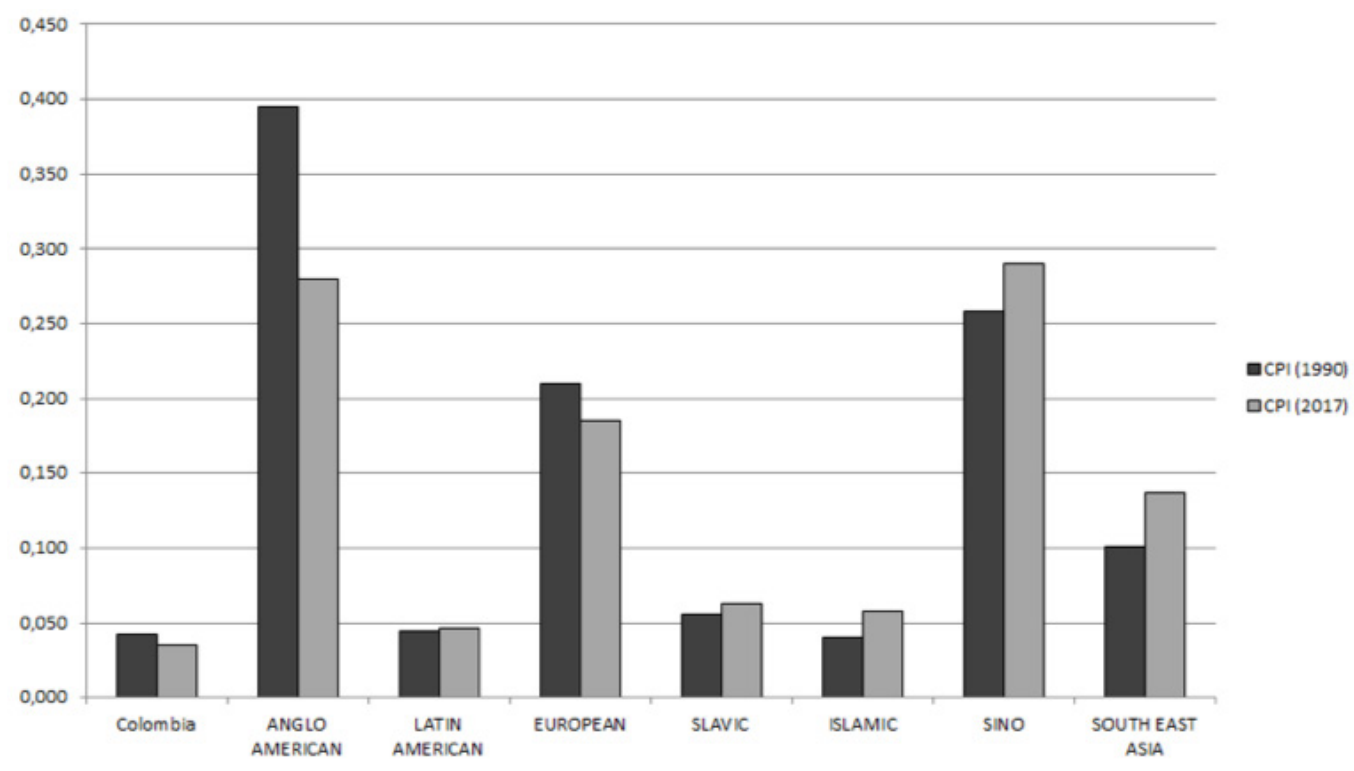

Source: Own construction with data from UNIDO (2019)

The Competitive Industrial Performance Indicator (CIP), composed by - among other factors - the share of medium- and high- tech activities in the productive system, the per capita manufacturing value added and exports, and the impact of the country in the world manufactures value added and trade, also corroborates the relative technological stagnation of the Colombian productive system compared to diverse cultural clusters across the globe. It is also possible to notice its decline in early developed regions (i.e. North America and Europe, especially the former), in favor of the more recently developed ones (i.e. the Sino and South East Asia).

Hitherto, based on the data presented, it is possible to gather that - compared to the rest of the world - in the last 25 years Colombia has had quite a poor performance in terms of industrial transformation, as shown in the meager industrial competitiveness levels and the persistent and increasing importance of raw materials as trading asset. The signs of industrial deterioration allow presuming that the country is no near close to revert those situations. By contrast, the newly industrialized ${ }^{7}$ economies of Asia (initially Japan; later Hong Kong, Singapore, South Korea, and Taiwan; later Indonesia, Malaysia, and Thailand, and more recently China) - merged here as the Sino and South East Asia clusters - have undergone rapid industrialization accompanied by

7 Scholars characterize as 'newly industrialized' those countries or regions that reached industrialization after World War II. 
economic growth, and a constantly-growing increasing participation of technologically sophisticated production in exports since the 1980s.

The Sino and South East Asian clusters appear to have been more successful moving towards products more complex than raw materials (herein termed 'Productive Transformation'), which is remarkable under our analytical standpoint (cultural traits) because it shows that successful processes of industrialization and tertiarization have been achieved by those 'newly industrialized economies' without having to extensively embrace 'western values' (e.g. Protestantism) to do so, and even more importantly, in spite of both the preexisting technological gap between them and their western counterparts, and of the recurrent attempts of the latter to 'kick away the development ladder' for the former (Chang, 2002, 2008).

The industrialization success of Asian countries has been discussed in detail elsewhere (See Birdsall et al., 1993; Fishlow et al., 1994; Stiglitz, 1996; Stiglitz \& Yusuf, 2001), so henceforth we will limit ourselves to outline and compare the aspects of the political economy of the process of productive transformation that allow us to underscore what - in our vision - are the cultural traits impeding industrialization in Colombia and promoting it in Asia.

\section{Colombian Productive Transformation}

During the nineteenth and well into the twentieth century Colombian economic policy was marked by the usage - inherited from the Spanish Colony - of raw material exports as the main - if not only - form of articulation with international markets (Kalmanovitz, 1994; Ocampo, 2007). Tentative local industrialization projects were further hampered by a small-scale internal market and by the geographical peculiarities that thwarted the political and economic connection between urban centers (Bushnell, 1996). Later on, the upsurge in the international demand of coffee, which initially helped in the development of a relatively stable source of income for a sector of the peasantry and the state (in the form of taxes), the enlargement of the transportation systems, and the embryonic accumulation of both capital and foreign currencies, eventually backfired and made the country coffee-dependent in terms of fiscal revenue, limited transport infrastructure development to the extraction of hinterland products to the ports, and gave the coffee growers association ${ }^{8}$ (National Coffee Federation) control over, initially purchase prices, but later, tax and credit rates, as well as exchange and monetary policies (Safford \& Palacios, 2002).

8 In Colombia, sectorial associations are denominated gremios. he direct translation to English is 'guild', but given that its primary definition relates to medieval powerful associations of craftsmen, henceforth we will use 'association' or the Spanish term indistinctively. 
Colombian economic policy at the beginning of the twentieth century responded largely to external shocks and delayed industrial development given that it was intended to benefit from cycles of boom in commodity markets (at the moment, its major trade asset) in what Ocampo (2013) calls a 'production-speculation model' underpinned to gold, tobacco and cinchona during the late part of the nineteenth century, and mostly coffee during the first half of the twentieth century. The raw material exports could not be discouraged in any way (e.g. custom duties) because they generated constant fiscal income and currency inflow, which were needed, the former to sustain the governmentled modernization programs and the latter to pay for the foreign machinery required for industrialization (Kalmanovitz, 1994, 2010), but thanks to its character - intensive in unskilled labor and non-intensive in capital goods (except perhaps oil) - the raw material exports gradually neglected the need for long-run multidimensional development programs like infrastructure, education, or institutional modernization. The success of the coffee sector for the Colombian society delayed the need for industrial development and turned Colombian economic orientation almost exclusively towards harnessing the coffee windfall.

When the international trade dynamic was broken, first by the crash of 1929 and later by the World Wars, and Colombia started to suffer the negative effects of the volatility in international commodity prices, Colombian manufacture took off through the production of basic consumer goods destined to the local market (Kalmanovitz, 1994, 2010; Ocampo, 2007), forced firstly by the international trade disturbances, and secondly by the post-war reversion of the international openness and multilateralism towards heavily protectionist reconstruction-related economic policies in developed countries, which reduced both the demand for Latin American exports as well as its sources of financial credit (Taylor, 2008).

Initially forced by global circumstances, but later following the Economic Commission for Latin America (CEPAL, in Spanish) recommendations for seizing a 'historical opportunity', Colombia - as most of Latin America - embarked after the Second World War and well until the 1980s in an inward-oriented and state-driven-and-supported industrialization strategy: to gradually replace manufactured imports with local production (Vazquez, 2017). In the midst of the global controversies regarding the establishment of international trade regulations (i.e. GATT), Colombia implemented protective tariffs, exchange rate stabilization programs and tax exemptions for input imports with aims to strengthen the manufacturing apparatus and to promote non-traditional exports in the line of the 'Import Substitution' programs in vogue, and which lasted for at least 30 years. Nevertheless, given that the inflow of currencies was being harmed by the increasing competition and the decline of the international price of coffee (the primary source of international currencies), the country struggled to keep exports in macroeconomically adequate levels through tax benefits, the creation of a specialized agency (PROEXPO), 
and the joint effort to create extended Latin-American markets for manufactured exports (Garay, 1998).

At the end, manufactures did grow, but not enough to promote neither type of Hirschmanian productive links. Additionally, the sectorial programs of industrial development lacked enough financial and administrative resources, and agricultural sector remained as the forerunner of the Colombian economy (Garay, 1998). Together with the aforementioned geopolitical context (international protectionism) and the local macroeconomic problems of slow growth of the internal market that was supposed to absorb the newly internally-produced and diversified manufactures - due mainly to poor infrastructure and unequal distribution of income- (Amézquita-Zárate, 2010; González, 2001), and the scarcity of skilled labor both as industrial workers and as higher-wage consumers (Kalmanovitz, 2010), three major issues obstructed the success of the Import Substitution Industrialization effort: "the firm's abuses of their [stategranted] dominant positions, [...] the private capture of [the] public [economic] regulator, $[\ldots]$ and, in general, the search of $[\ldots]$ private rents derived from public decisions and measures" (Posada, 2008, p. 63).

We posit that Posada's tenet was especially patent in the second half of the twentieth century, when a plethora of associations emerged to advocate for the inclusion of their interests in the economic legislation ${ }^{9}$, or directly legislate on them (when policymakers were also entrepreneurs or vice versa). The perks of having a hotline to the (or directly acting as) economic authorities included prerogatives such as preferential credit lines (de fomento) granted by the Colombian Central Bank and governmental subsidies to specific sectors (Maya, 2002) as well as reductions in corporate and land property taxes (specially for large states). Ultimately, the 'rent capture' dynamics promoted the local and immediate interests of specific groups at the expense of rest (Garay, 1998).During the 1980s and 1990s, under the aegis (also credit-oriented pressure) of the Washington Consensus and its institutions, the economic policy suffered a cardinal shift when Colombia reversed the industry-protective (for us, association-protective) framework in an upsurge of total liberalization called 'Apertura' (opening) (Meléndez \& Perry, 2010), to focus in the so-called pillars of the 'new' approach to development: free markets and stable currencies (Maya, 2002). The industrial promotion impetus was lost firstly because of structural insurmountable difficulties in terms of the provision of basic services such as energy, transport and telecommunications (a recurring problem all along Colombian economic history), but especially because of new mineral bonanzas: Coal in 1978, and Oil in 1983

9 Junguito (2019) lists, among many more the, National Industrial (Entrepreneurs) Association (ANDI, 1944), National Traders Federation (FENALCO, 1945), National Federation of Rice Growers (FEDEARROz, 1947), Small and Medium Enterprises Association (ACOPI, 1951), National Sugar Cane Growers Association (AsocaÑa, 1959), National Federation of Palm Oil Growers (Fedepalma, 1962), National Federation of Cattle Ranchers (FEdEgAn, 1963), National Foreign Trade (Exporters) Association (ANALDEx, 1971), Colombian Association of Flower Exporters (ASOCOLflores, 1973), Colombian Federation of Potato Producers (FEdePAPA, 1974). 
and 1989 (Glavijo, Vera, \& Fandiño, 2012). Again, industrial development was pushed into the background, this time, in order to harness the mineral windfall.

The latest productive transformation paradigm adopted by Colombia between 1998 and 2002, broadly baptized as "competitiveness" and in which the state coordinates integrative activities and provide public services rather than subsidies and protection, has created "advisory committees in five transversal areas: firm management, productivity and quality; technology; human resources; infrastructure; regulatory and legal frameworks" attempting to promote the productive and export capabilities of specific "production chains" in view of the increased import competition (Meléndez \& Perry, 2010, pp. 5-6), but especially to exploit the opportunities open by the signature of multiple Free Trade Agreements. Nevertheless, as the same authors remark, the coordination channels have been too transactional, personal and dominated by clientelist and rentseeking relations, "open mostly for large firms, powerful business associations or groups with local political power" (p. 24), the policies are not coherently bonded together, and by virtue of the constant institutional, content, goal and implementation changes, not sustainable or enduring.

\section{Asian Productive Transformation}

Asian industrialization began in the early 1960s when "Hong Kong, Korea, Singapore, and Taiwan began investing in light, labor-intensive manufacturing industries whose products were quickly able to penetrate the lower and the most price-sensitive end of markets in Western countries [e.g. garments, footwear, and consumer electronics]" with a view to gradually improve the quality and variety of manufactured exports (Chea, 2012, p. 92). Later, in the 1980s these "newly industrialized economies shifted into more capital-and-skill-intensive manufacturing industries [such as machinery, electronic, chemicals, and transport industries] and Western and Japanese corporations began investing in local firms and establishing wholly owned facilities to leverage the advantages of lower labor and overhead costs" (Chea, 2012, p. 92).Even though the 'Asian miracle' process and results were not homogeneous for all the countries, we summarize the comprehensive analysis made by Quibria (2002) as follows: openness to trade and technology provided new economic opportunities in international markets, created competitive pressures for the domestic economy, and allowed access to new technologies through imports of new machinery and equipment — which is useless without the properly skilled workers - whereby more sophisticated production pushed both public and private investment in education. The services sector blossomed thanks to the demand of accounting, legal, marketing and public relations services. Given that "irrespective of the initial impetus, a virtuous circle between investment and growth can only be sustained by a strategy of outward orientation [...] after an early phase of import substitution, 
the miracle economies embarked on a strategy of outward orientation" (pp. 23-24) with aims to create a "virtuous circle of accumulation and assimilation", this is, learning to produce, produce and export, but only until the 1980s and 1990s the region reduced import tariffs and nontariff barriers, under the idea that "outward orientation does not necessarily mean [fully] free trade" (p. 23). More sophisticated exports improved the terms of trade and provided currencies to gradually and safely open imports.

Quibria (2002) also quotes debates about the institutional side of the 'miracle' and concludes that all the aforementioned was possible because of favorable conditions set by macroeconomic stability, labor market flexibility, and good economic governance more often than not enforced by authoritarian or semi-authoritarian regimes - which favored the arrival of investment through credible and time-consistent policies, governmental accountability and a strong rule of law. Nonetheless, he also remarks that Asian governments exerted diverse levels and types of intervention, with cases such as (a) Hong Kong with minimal or inexistent industrial policy, (b) South Korea as one of "the most ardent practitioners of industrial policy" (p. 47) providing conditioned protection and subsidized credit to selected industries, yet subject to "strict performance standards defined in terms of export targets" (Amsden, quoted in Quibria, 2002) which minimized the prevalent rent-seeking activities resultant from similar policies elsewhere, and (c) the governmental interventions in "Indonesia, Malaysia, and Thailand [which] were more often guided by political considerations (that is, supporting individuals, families, and firms in return for political favors) than by economic considerations [and which] failed miserably in terms of economic objectives" (Quibria, 2002, p. 50).

With both successes and failures based on both heavy and light governmental intervention in diverse economic and social areas, and with fluctuations and particular dynamics in each country, Quibria argues that the economies that followed free market approaches tended to be more successful than those based on patronage relations, but that in general the region positive social economic results are undeniable. The indicators we presented in the previous section are in line with those conclusions.

\section{Discussion}

In previous pages we portrayed Colombia, compared to different cultural clusters and to more technologically mature clusters, as a tolerant to authoritarian structures, less individualistic (more communalistic), more inclined towards material achievements, relatively intolerant to uncertain situations, and especially short-term oriented society. We contend that those cultural characteristics are a key factor explaining the historical tendency of Colombia to rest on natural resources bonanzas rather than decidedly promoting industrialization. 
Away from the respective geopolitical and macroeconomic issues of each region that promoted or impeded industrialization and which are extensively discussed elsewhere, we will emphasize two dimensions that give ground to our analysis of the cultural hypothesis related to productive transformation. Namely, the temporal dimension of the policies and the clashing interests of the Colombian associations (gremios). The biggest example of that clash is described by Caballero Argaez (2016) when he observes that

The interests championed by coffee producers and industrialists in the conduction of economic policy were [divergent]. The goal of the former was to increase their income in local currency, for which they favored the devaluation of Colombian peso; the goal of the latter was to supply the internal market with more national products for which they needed an overvalued exchange rate. [Consequently, representing $80 \%$ of total exports] the external prices of coffee determined the internal cycles of the Colombian economy for seventy years (p. 11$)^{10}$.

Several works on Colombian history have asserted that the government-private sector symbiosis has been based on the exchange of direct subsidies and tax benefits for currencies and tax revenues (e.g. Bushnell, 1996; Kalmanovitz, 2010; Safford \& Palacios, 2002). Rettberg (2001) remarks the close ties between the political and economic elites and their rallied influence over economic policy through both formal (governmental advisory bodies) and informal (private requests) processes, commonly materialized in special licenses and permits, and annotates that gremios historically have been "very effective channeling privileges to their constituency" (p. 4).

During a first moment (nineteenth century and first half of the twentieth century) the transactional rapport involved raw material exporters and the state, and later (after the second half of the twentieth century) expanded to include the local entrepreneurs producing manufactures destined to the local market. In both cases, not infrequently the grantor and the grantees happened to be the same people, or closely related. Kalmanovitz (2000) points out that selective protection in the form of direct subsidies, tax benefits, preferential tariffs, licenses, permits, advantageous credit, etc., for one part, contains vestiges of traditional intervention systems with no clearly defined objectives, in which each party (i.e. the state, sectorial associations, government officials and entrepreneurs) fights to secure niche compensations, and for the other, propagates individualism and corruption given that the policymakers and their political figures (councilmen, congressmen) use the compensations to safeguard election (and reelection) through the beneficiaries of their policies, while the average citizen lives under a system of 'taxation with no representation'. This situation displays the Kaufmanian characteristics of clientelism (Brinkerhoff \& Goldsmith, 2002): it is based and maintained by reciprocity and economic calculations, and it is particularistic, private, and loosely embedded in public laws, although — in our view - in the Colombian case, it occurs between actors endowed 
with similar levels of power (read, economic and political elites). If the protection is scheduled to be dismantled or relocated to another underserved group, the voices of the beneficiaries rise in protest, especially echoed by the political entrepreneurs relevant to that specific clientele.

For us, the low Individualism (IDV) of the Colombian culture - according to the HCDis just group individualism in disguise. Colombian society is highly individualistic in the sense of a prevailing 'everyone for himself' logic, as exemplified in sectoral associations organized to defend only their specific interests and no one else's; something described by the HCD approach to individualism as a marked tendency "to take care of only themselves and their immediate families" (Hofstede Insights, 2017). Gremios - following that description - operate then as 'immediate families' using economic policy for their immediate interests. The potential origin of such phenomenon might lie in two aspects. First, the historical geographical separation of urban, political and economic centers, which by reinforcing socio-economic differences has created deeply ingrained regionalism and cultural and political antagonisms (Bushnell, 1996), and second, the Kaufmanian clientelist political structures described by Kalmanovitz in our previous paragraph.

Colombian collectivism (group individualism in practice) has forestalled industrialization by concentrating the state economic policy in the interests of determined economic groups, be it because of its closeness to the political elites, because of its incidental importance in the national economy (e.g. coffee, oil) or because of the urge to exploit a momentary windfall (e.g. coffee, oil) before it fades, more often than not, at the expense of other economic or social groups. The strong influence of the Colombian National Coffee Federation in the foreign exchange policy, which for almost fifty years forced currency devaluations in order to guarantee the income of the coffee sector in the face of the international prices decline (Durán, 2008) is the most prominent example. One obvious implication is that albeit the incoming stream of currencies, the depreciated peso - also defended on the grounds of the substitution of expensive imports with local production - left the manufacturing sector struggling to import machinery and production inputs. The coffee sector flourished at the expense of other economic sectors.

Whilst East Asian countries industrialized under a market model in which institutions and agents encourage and maintain relational links that go beyond the isolated and impersonal 'least-cost supplier', and that is organized through synchronized networks (Lajciak, 2017) that build Hirschmanian forward and backward linkages, Colombian industrialization — or lack of it - has been the result of the creation of shelter circles that seldom overlap or tangentially touch (one exception could be the cattle ranchers and landowners common struggle for land property). Each circle endorses the interests within the circle disregarding its potential negative effects on other circles. The HCD low individualism (or high communalism) score for Colombia simply means high communal 
— as in 'group' - individualism. Colombian associations turned economic policy in a zero-sum game.

On the other hand, after the World Wars, with poorly connected economic centers, low levels of education resulting in low levels of skilled labor and low levels of income, and high levels of social and economic inequality leading to high levels of social unrest (often violent), Colombia faced similar challenges to those of the Sino and South East Asia cultural clusters in terms of social and productive transformation, but while the latter radically transformed its productive apparatus between 1960 and 1980, in the last three decades Colombia has not had major industrial transformation, evidenced by the poor - and declining - industrial competitiveness indicators and the persistent and increasing importance of raw materials in exports. This can be explained because

The evolution towards more diversified productive structures require the implementation of science, technology and innovation programs, that allow to incorporate new technologies, improve scientific capabilities, manage knowledge and technology in a better way, with the primary purpose of accessing higher productivity levels that allow to increase the number of qualified jobs and to improve the social conditions of countries (Alonso, as quoted in LópezArellano \& Montoya-Grajales, 2016, p. 7)

The inability of Colombia to diversify its productive structures lies in the conjunction of three HCD cultural dimensions: Masculinity (MAS), Uncertainty Avoidance (UAI) and Time Orientation (LTO). Colombian society displays high materialism, low tolerance to uncertainty and short-term orientation, respectively, for which it prefers tangible and immediate outcomes, making long-term undertakings such as infrastructure, educative and scientific transformations — which related works agree in considering key for 'Economic Development' - largely unfeasible.

Regarding infrastructure, Jaramillo (2004) — quoted in extenso in the following lines remarks that Colombian infrastructure has tended to be more notorious for the judiciary controversies surrounding it (corruption, protracted and inconclusive judicial processes, contractual breaches by the concessionaires, etc.) than for its progress. With an average investment of 0.9 of the GDP in its development, Colombia falls way behind the 2.0 of the GDP average invested by Latin America and shows no sign of improvement even after decades of the 'Apertura' process. The three biggest cities in terms of GDP production (Bogotá, Medellín and Cali, with 80\%) are not properly connected between them or with the coast ports, and at least $45 \%$ of the roads in the country remain unusable due to poor or undergoing maintenance. Cargo transportation is made mainly with trucks that make haulage slow and expensive. Railroads are used exclusively for transporting minerals from the extraction site to the port, because existing passenger or non-mineral cargo lines are economically impractical and only $61 \%$ of the infrastructure is only partially active, with the remaining $39 \%$ out of service and completely unrecoverable. Colombian land connections with neighboring countries and multimodal transportation 
systems are limited. The major ports have very limited storage and volume handling capabilities, and are unreachable for large-size (post-Panamax) ships; besides, the road access to ports is often in poor condition. Airports are lagging behind the increases in both passengers and airlines demand, and the major cities show deteriorated road networks and mobility bottlenecks due to the administrative incapacity to address the problems and the preference for short-term solutions ${ }^{11}$.

Regarding technological innovation programs, Pérez (2015) coincides with us in connecting the greater importance given by the country to raw materials exports and products with low added value to the reduced need for innovations and technological development. She quotes Garay to mention that Colombian industry centered in the foods, beverages, tobacco, apparel, furniture, printing and leather manufactures - we contend, safer bets given the nature of the Colombian market and its dynamics - and then she highlights the meager levels of investment in science, technology and research by the corporate, government and academic spheres under the tacit belief that only industrialized countries can 'do science' and that for Colombia is better to import it and adapt it to local needs, allowing to redirect those resources towards more 'immediate' needs.

In addition to the productive direction, Pérez (2015) also remarks that while governmental institutions for the promotion of science, technology and innovation were created as early as the 1960 s, only two decades later those initiatives materialized, timidly, into working research groups and centers or partnerships between the industrial sector and the academia. Finally, the links between academia and productive sectors have been weak because of the national economic policy priorities (export of raw materials) that generate low levels of scientific demand from the productive sector, added to continued political and economic instability, according to Sagasti (also quoted in Pérez).

Those two problematic issues (infrastructure and technological innovation) have in common the influence of three cultural dimensions (short-term orientation, materialism and uncertainty avoidance) as a hindrance for productive transformation in Colombia.

In terms of infrastructure development, historically Colombia has been particularly sensitive to two factors. First, decades of vulnerability derived from the protracted armed conflict between the state and left-wing guerrillas that has resulted in damages to economic infrastructure through bombings, extortions, and kidnappings of employees (Pizarro Leongómez, 2006). Second, decades of chronic corruption embodied in irregular contracts, direct contracting (with rigged public bids or none whatsoever), contract breaches, cost overruns, and the ensuing interminable legal procedures confronting the state against construction firms (Corporación Transparencia por Colombia, 2019), which flourish in a "rule-disregard culture" combined with institutional weakness (for prevention and punishment) and political clientelism (Newman \& Ángel, 2017). 
For us, the first factor (armed conflict) increases risk and uncertainty for public or private investors, which according to Goel and Ram (2013) correlates positively with corruption given that under higher uncertainty economic agents tend to focus in the present and to be more inclined towards offering and demanding bribes to secure gains, thereby promoting the second factor. The conflict-generated uncertainty curbs infrastructural investments as a result of the increasing costs and risks arising from less stable macroeconomic and political conditions, particularly manifest in low income countries (OECD, 2015). Furthermore, the higher levels of uncertainty might also explain the historical bias of Colombia towards raw material exports over the development of value-added manufactures on the grounds of relatively secure and more immediate income, as opposed to technologically sophisticated products which require large initial investments and yield positive returns only in the long-term. Colombia has suffered armed conflict for most of its history, making uncertainty a widespread and permanent condition, forcing economic actors to focus in immediate and tangible yields which after seized, must be protected by all means.

In the same line, the aforementioned Colombian short-term orientation, materialism and uncertainty avoidance also influence negatively what Crespi, Fernández-Arias, and Stein (2014) call "investing in ideas" in the sense that "the returns to innovation investments are more uncertain [...] involve longer gestation lags [and] normally include a large proportion of intangible assets (such as human capital) that have very limited use as collateral", which they remark as an obstacle for technological improvement in low income countries given that "innovation projects may not materialize due to lack of access to financing or to the high cost of capital" (p. 67). With the constantly malfunctioning and/or threat over the rule of law, the respect for property rights, and physical security, private actors will hardly embark in long-wait scientific or industrial projects; neither will a public sector in dire for resources to cover so many malfunctioning and/ or threatened social fronts.

On the other hand, Chea (2012) - quoting previous researches - argues that East Asian economies initiated and supported technological progress - broadly speakingthrough the improvement of human capital; the financial support to public research institutions; grants, subsidies and tax incentives for scientific research activities; and technology transfer through foreign direct investment in high-tech, and information industries (p. 94). As we already mentioned, the Asian productive transformation started in the 1960s with resolute policies favoring labor-intensive manufacturing industries, while Colombia has most of the time opted for grants, subsidies and tax incentives to raw material exports that given its predominant cultural traits constitute a safer economic bet in the short-term. The sectoral associations, the firms, the politicians and the officials in charge of economic policy have consistently advocated for their immediate interests and those of their immediate circle, disregarding the (future) general welfare of the country 
as a whole. By contrast, the Sino and South East Asia clusters, with much more long term orientation (LTO) and more tolerance to uncertainty (UAI) have favored industrial policies with more uncertain and long-wait results, and even though there also has been heavy protection to specific sectors, it has promoted Hirschmanian linkages to other industries and spillovers to diverse segments of the society. In Colombia, by its design, the protection rarely goes beyond the lobbyist group and the social compensation required from the recipients of subventions is unclear.

In spite of being equally materialistic (high Masculinity levels according to HCD) to Colombia, the recent industrialization of Asia (here, the Sino and East Asian cultural clusters) has been possible because of its higher willingness to accept the risks associated with the development of industries in which it had no previous experience (lower Uncertainty Avoidance according to HCD) and its readiness to 'sacrifice' immediate outcomes for future ones (higher Long-Term Orientation according to HCD). The first tangible results of the investments in light manufacturing industries came twenty or thirty years later to the region, then it was struck by a massive financial market crisis in 1997, but after a painful recovery currently holds 28\% of the global GDP, earning itself the nickname of "the World's Factory" (The Economist, 2014, may 30).

Following Morrissey and Filatotchev (2000) (from our preliminary concepts), the outstanding integration of the Asian clusters into international markets of consumer and capital goods reflects the private competence to face international competition and the public competence to establish adjuvant policies; following UNCTAD's (2016) argument on the virtues of manufacturing, higher levels of socio-economic development have been achieved thanks to the internal and external linkages that sustain the virtuous circle of growth and structural transformation; and following Inglehart and Welzel (2005), the economic, political, social and cultural transformations undergone by the Asian clusters in the process of industrial modernization (i.e. 'Productive Transformation') have helped in the gradual process of social modernization.

All in all, key factors for productive transformation (human capital formation, infrastructure development and scientific and technological investment) represent long-term undertakings that are at odds with the immediate and tangible results that uncertainty demands in the Colombian society, consequently, in a community besieged by armed conflict, social and economic inequality and political corruption, the "politics of survival" (Migdal, quoted in Brinkerhoff \& Goldsmith, 2002) tend to prevail.

\section{Conclusions}

While it is true that industrial policy is difficult to implement given the complexities of "targeting, sequencing, and fine-tuning industrial interventions" (Quibria, 2002, p.48), 
the Asian 'miracle' shows that using it more like a catalyst to provide favorable conditions (Stiglitz, 1996) rather than concentrating all efforts and resources in assisting specific groups could be more helpful for both productive transformation and social and economic development. This contention highlights the importance of institutional arrangements and sound economic policies rather than cultural traits as determinant for economic development; nevertheless, both institutional arrangements and economic policies obey to the shared beliefs, values, customs, and behaviors embedded in the local culture, in other words, an ethos, a mentality.

Even if (a) the ways in which cultural traits influence economic performance are diffuse and ambiguous, (b) no specific cultural trait can be considered per se as detrimental or advantageous to economic development, and (c) the paths of development for each culture or country are not predetermined, cultural traits can neither be completely taken out of the picture nor considered as the whole explanation of economic development or underdevelopment. Chang (2008) remarks that "before the East Asian economic 'miracle', people used to blame Confucianism for the region's underdevelopment” (p. 445). Additionally, the cultural values currently displayed by economically developed countries might as well be the consequence of such development rather than its cause (See Inglehart \& Baker, 2000).

Nevertheless, culture can exert strong influence over economic performance by modifying the precepts under which the decisions are made, the allocation of resources is done, the goods are produced, the capital flows, and the outcomes of economic activity are distributed. For its part, economic policy does have a cultural component in it, because both the complying population and the policymakers are immersed within a 'dominant' culture with a specific mentality that guides their choices and actions. On the other way around, cultural values are affected by economic development because the economic environment modifies the conditions in which people live, their priorities, and the available options they have to confront the vicissitudes of life.

Productive transformation - the focus of this work - does not emerge from cultural traits alone. Resolute political action (such as that evidenced by the Asian 'miracle') is imperative to establish the institutions and conditions required for productive transformation and economic development. Latin America, the Muslim world, Africa and Colombia suffer from a deep rooted extractive institutionalism rather than from laziness, low intellectual coefficient, excessive 'folklore', or lack of entrepreneurship (De Soto, 2000). The Sino and East Asia cultural clusters we presented have achieved a considerable level of economic development - as a consequence of industrialization - not only with radically different cultural traits - proving that western culture was not the only arrangement convenient for the task - but under harder competition conditions, higher markets integration, faster product innovation and a more complex business environment, and did so by employing an effective combination of political actions during critical historical 
junctures rather than relying completely on its natural resources endowments or modifying its traditional values.

Inconsistent with its low tolerance to uncertainty, Colombia for the most of its history has depended - economically speaking - of price-volatile and demand-uncertain raw materials, while under the same principle has kept the countrywide development of its infrastructure, scientific or competitiveness capabilities on hold, sponsored by an installed capacity functional enough to allow the country to rely upon the short-term and tangible gains of its natural resources, something that is congruent with its low LongTerm Orientation (according to HCD) and with its low Individualism (for us, group individualism in disguise) that has allowed specific groups to control and benefit from economic policy (legally and not), widely in detriment of the general public. Furthermore, Colombian tensioning political, social and economic situation has arguably accentuated within the general population, the economic elites, and the policymakers a certain set of values (short-term orientation, materialism, intolerance to uncertainty, individualism), and those values have ultimately influenced economic policies favoring extractive endeavors - tangible in the short term - over industrial or scientific - intangible, and long-term-contingent - ones. A tendency that is visible in the deterioration of both the Competitive Industrial Performance Indicator (CIP) and the Composition of Exports in terms of Added-Value.

While further research is required about the conditions that have held infrastructural, industrial, and technological development back in Colombia, as well as the effective prevalence, dynamics and real influence of the cultural traits reported by the HCD in Colombian society and its economic policy, we conclude that Colombian economic policy has evidenced a tendency to follow a short-term, materialistic, intolerant to uncertainty, and (group) individualistic orientation (read, mentality) that have kept the industrial structure of the country lagging behind, especially to deal with current and emerging challenges of the global economy such as violent conflict, migrations, extreme inequality, environmental sustainability, or the technological replacement of humans jobs.

\section{Acknowledgements}

This article was possible thanks to a grant from the University of Lisbon. The author is also grateful to the anonymous reviewers and editors for helpful comments which greatly improved the manuscript. 


\section{References}

Amézquita-Zárate, P. (2010). La política de Industrialización por Sustitución de Importaciones: El contexto Colombiano. GCG: revista de Globalización, Competitividady Gobernabilidad, 4(2), 40-53. doi: 10.3232/GCG.2010.V4.N2.03

Arndt, H. W. (1981). Economic Development: A Semantic History. Economic Development and Cultural Change, 29(3), 457-466.

Birdsall, N. M., Campos, J. E. L., Kim, C.-S., Corden, W. M., MacDonald, L. E., Pack, H., . . S Stiglitz, J. E. (1993). The East Asian Miracle: Economic Growth and Public Policy. New York: The World Bank.

Brinkerhoff, D. W., \& Goldsmith, A. A. (2002). Clientelism, Patrimonialism and Democratic Governance: An Overview and Framework for Assessment and Programming (pp. 1-50). Cambridge: Abt Associates Inc.

Brinkman, R. (1995). Economic Growth versus Economic Development: Toward a Conceptual Clarification. Journal of Economic Issues, 29(4), 1171-1188. doi: 10.1080/00213624.1995.11505746

Bushnell, D. (1996). Colombia: Una nación a pesar de sí misma / De los tiempos precolombinos a nuestros días. Bogotá: Editorial Planeta.

Caballero Argaez, G. (2016). La economía colombiana del siglo XX. (Kindle Version): Debate.

Clavijo, S., Vera, A., \& Fandiño, A. (2012). La Desindustrialización en Colombia / Análisis Cuantitativo de sus Determinantes. Bogotá: Asociación Nacional de Instituciones Financieras (ANIF).

Corporación Transparencia por Colombia. (2019). Así se mueve la corrupción / Radiografía de los hechos de corrupción en Colombia 2016-2018 (pp. 1-96). Bogotá: Corporación Transparencia por Colombia.

Crespi, G., Fernández-Arias, E., \& Stein, E. (2014). Rethinking Productive Development / Sound Policies and Institutions for Economic Transformation. New York: Inter-American Development Bank.

Chang, H.-J. (2002). Kicking Away the Ladder / Development Strategy in Historical Perspective (1 ed.). London: Anthem Press.

Chang, H.-J. (2008). Bad Samaritans: The Myth of Free Trade and the Secret History of Capitalism. (Kindle Version): Bloomsbury Press. 
Revista CIFE / ISSN: 0124-3551 e-ISSN: 2248-4914 / Bogotá-Colombia / Vol. 21 N. o 35 / julio-diciembre 2019 / pp. 105-139

Chea, A. C. (2012). The East Asian Development Experience: Policy Lessons, Implications, and Recommendations for Sub-Saharan Africa (SSA) Global Competitiveness. International Journal of Academic Research in Business and Social Sciences, 2(7), 82-122.

De Soto, H. (2000). The mystery of Capital: Why Capitalism triumphs in the West and fails everywhere else. (Kindle Version): Basic Books.

Durán, I. M. (2008). La Federación Nacional de Cafeteros y la política cambiaria en Colombia 1923-1973: Una aproximación historiográfica. Ensayos de Economía, 18(32), 79-98. doi: 10.15446/ede

Edwards, Z. (2016). Economic Development. In A. D. Smith, X. Hou, J. Stone, R. M. Dennis \& P. S. Rizova (Eds.), The Wiley Blackwell Encyclopedia of Race, Ethnicity, and Nationalism (1 ed., Vol. II). Oxford: John Wiley and Sons Ltd.

Fishlow, A., Gwin, C., Haggard, S., Rodrik, D., \& Wade, R. (1994). Miracle or design? Lessons from the East Asian Experience. Washington DC: Overseas Development Council.

Fowler, N. (2012, September 19). Montesquieu's Socio-Political Climate Theory. Prospect / Journal of International Affairs at University of California San Diego. https: / / prospectjournal.org/2012/09/17/montesquieus-socio-political-climate-theory/

Garay, L. J. (1998). Colombia: Estructura Industrial e Internacionalización 1967-1996. Bogotá: Departamento Nacional de Planeación.

Gil Villegas, F. (2015). Max Weber y la guerra académica de los cien años: Historia de las ciencias sociales en el siglo XX / La polémica en torno a La ética protestante y el espiritu del capitalismo (1905-2012). (Kindle Version): Fondo de Cultura Economica.

Goel, R. K., \& Ram, R. (2013). Economic uncertainty and corruption: evidence from a large cross-country data set. Applied Economics, 45(24), 3462-3468. doi: $10.1080 / 00036846.2012 .714073$

González, J. I. (2001). Entre la sustitución de importaciones y la apertura. In G. Misas (Ed.), Desarrollo económico y social en Colombia. Siglo XX (pp. 399-425). Bogotá: Universidad Nacional de Colombia.

Guiso, L., Sapienza, P., \& Zingales, L. (2006). Does Gulture Affect Economic Outcomes? Journal of Economic Perspectives, 20(2), 23-48.

Hofstede, G. (2015). Dimension Data Matrix. from https://geerthofstede.com 
Hofstede, G., Hofstede, G. J., \& Minkov, M. (2010). Cultures and Organizations / Software of the Mind / Intercultural Cooperation and its Importance for Survival (3 ed.). New York: McGraw-Hill.

Hofstede Insights. (2017). National Culture. from https://www.hofstede-insights.com/ models/national-culture/

Inglehart, R., \& Baker, W. E. (2000). Modernization, Cultural Change, and the Persistence of Traditional Values. American Sociological Review, 65(1), 19-51.

Inglehart, R., \& Welzel, C. (2005). Modernization, Cultural Change and Democracy: The Human Development Sequence. Cambridge: Cambridge University Press.

Jaramillo, L. F. (2004). El estado de la infraestructura en Colombia frente al reto de la globalización. Poliantea, 1(2), 129-152. doi: 10.15765/plnt.vli2.362

Jolley, A. (2013). Global Villages. from https://itsallaboutculture.com/ global-villages-map/

Junguito, R. (2019). El papel de los gremios en la economía colombiana. Revista Desarrollo y Sociedad, 82(4), 71-100. doi: 10.13043/dys.82.4

Kalmanovitz, S. (1994). Economía y nación: una breve historia de Colombia (4 ed.). Bogotá: Tercer Mundo S.A.

Kalmanovitz, S. (2000). El modelo anti-liberal colombiano. Conferencia en el Seminario Hacia la construcción del modelo de desarrollo económico y social para Colombia. Universidad de los Andes. Bogotá. Retrieved from http:/ /www.banrep.gov.co/documentos/presentaciones-discursos/pdf/modelantiliberal.pdf

Kalmanovitz, S. (2010). Nueva historia económica de Colombia. Bogotá: Taurus / Fundación Universidad de Bogotá Jorge Tadeo Lozano.

Kapás, J. (2017). How Cultural Values Affect Economic Growth: A Critical Assessment Of The Literature. Ekonomska Misao I Praksa (Economic Thought and Practice)(XXVI), 265-285.

Lajciak, M. (2017). East Asian economies and their philosophy behind success: Manifestation of social constructs in economic policies. Fournal of International Studies, 10(1), 180-192. doi: 10.14254/2071-8330.2017/10-1/13

Lin, J. Y., \& Treichel, V. (2014). Making industrial policy work for development. In J. M. Salazar-Xirinachs, I. Nübler \& R. Kozul-Wrigh (Eds.), Transforming Economies: Making 


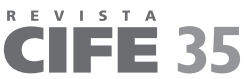

Revista CIFE / ISSN: 0124-3551 e-ISSN: 2248-4914 / Bogotá-Colombia / Vol. 21 N. 35 / julio-diciembre 2019 / pp. $105-139$ industrial policy work for growth, jobs and development (pp. 65-78). Geneva: International Labour Organization.

López-Arellano, H., \& Montoya-Grajales, W. D. (2016). Análisis de la política de transformación productiva colombiana, basada en la incorporación de la ciencia, la tecnología y la innovación, para el mejoramiento de la competitividad de Colombia entre los años 2010 y 2014. Revista Electrónica Educare, 20(3), 1-22.

Lopez-Claros, A., \& Perotti, V. (2014). Does Culture Matter for Development? Policy Research Working Paper No. 7092. World Bank Group. Washington. Retrieved fromhttp://documents.worldbank.org/curated/en/104741468325132310/ Does-culture-matter-for-development

Maya, G. (2002). Colombia 1990-2000: Globallzación y Crisis. Ensayos de Economía, 12(20-21), 117-174. doi: 10.15446/ede

Meléndez, M., \& Perry, G. E. (2010). Industrial Policies in Colombia. IDB Working Paper No. 37. Inter-American Development Bank. Retrieved from https://ssrn.com/ abstract $=1817239$

Michaels, F. S. (2011). Monoculture: How One Story is Changing Everything. (Kindle Version): Red Clover Press.

Morrissey, O., \& Filatotchev, I. (2000). Globalisation and Trade: The Implications for Exports from Marginalised Economies. The Journal of Development Studies, 37(2), 1-12. doi: 10.1080/713600066

Newman, V., \& Ángel, M. P. (2017). Sobre la corrupción en Colombia: marco conceptual, diagnóstico y propuestas de política. Cuadernos de Fedesarrollo No. 56. Fedesarrollo / Dejusticia. Bogotá. Retrieved from https://www.dejusticia.org/wp-content/uploads/2017/08/ CDF_No_56_Agosto_2017.pdf

Ocampo, J. A. (2007). Historia económica de Colombia. Bogotá: Editorial Planeta Colombiana S.A.

Ocampo,J. A. (2013). Colombiay la economía mundial 1830-1910(2 ed.). Bogotá: Universidad de los Andes.

Organisation for Economic Cooperation and Development (OECD). (2015). Risk and Return Characteristics of Infrastructure Investment in Low Income Countries G20 Development Working Group (pp. 1-28). Antalya: Organisation for Economic Cooperation and Development (OECD), 
Peet, R., \& Hartwick, E. (2009). Theories of Development: Contentions, Arguments, Alternatives (2 ed.). New York: The Guilford Press.

Pérez, M. (2015). Alcances de las Políticas Nacionales de Ciencia, Tecnología e Innovación en el Departamento del Atlántico. Psicogente, 18(34), 406-419. doi: 10.17081/psico.18.34.515

Pizarro Leongómez, E. (2006). Las FARC-EP: ¿Repliegue estratégico, debilitamiento o punto de inflexión? In F. Gutiérrez, M. E. Wills Obregón \& G. Sánchez (Eds.), Nuestra guerra sin nombre / Transformaciones del conflicto en Colombia (pp. 171-207). Bogotá: Instituto de Estudios Políticos y Relaciones Internacionales (IEPRI) Universidad Nacional de Colombia / Grupo Editorial Norma.

Posada, C. E. (2008). Comentario a "Hirschman, la industrialización y la teoría del desarrollo". Desarrollo y Sociedad(62), 41-65.

Quibria, M. G. (2002). Growth and Poverty: Lessons from the East Asian Miracle Revisited. ADB Institute Research Paper No. 33. Asian Development Bank. Tokyo. Retrieved from http://hdl.handle.net/11540/4139

Rettberg, A. (2001). Dos crisis, dos desenlaces: Retos realidades del empresario organizado colombiano en los años cincuenta y noventa. Revista de Estudios Sociales(8).

Rist, G. (2008). The History of Development / From Western Origins to Global Faith (3 ed.). London: Zed Books Ltd.

Roa, A. (2016). ¿Por qué Bogotá no tiene al menos una línea metro? Y las razones por las que probablemente no la tendrá. Opera(19), 139-159. doi: 10.18601/16578651. n 19.08

Safford, F., \& Palacios, M. (2002). Colombia: Fragmented Land, Divided Society. New York: Oxford University Press.

Sahuquillo, I. M. (1997). Los dos conceptos de cultura: Entre la oposición y la confusión. REIS: Revista española de investigaciones sociológicas(79), 173-196. doi: $10.2307 / 40184012$

Stiglitz, J. E. (1996). Some Lessons from the East Asian Miracle. The World Bank Research Observer, 11(2), 151-177.

Stiglitz, J. E., \& Yusuf, S. (2001). Rethinking the East Asia Miracle. Oxford: The World Bank / Oxford University Press.

Taylor, A. (2008). In V. Bulmer-Thomas, J. Coatsworth \& R. Cortes-Conde (Eds.), The Cambridge Economic History of Latin America (pp. 57-100). Cambridge: University Press 


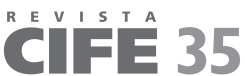

Revista CIFE / ISSN: 0124-3551 e-ISSN: 2248-4914 / Bogotá-Colombia / Vol. 21 N.o 35 / julio-diciembre 2019 / pp. 105-139

The Economist. (2014, may 30). A world to conquer. The Economist. https://www.economist.com

United Nations Conference on Trade and Development (UNCTAD). (2016). Trade and Development Report 2016 (pp. 57-95). Geneve: The United Nations Conference on Trade and Development,.

United Nations Industrial Development Organization (UNIDO). (2019). UNIDO Statistics Data Portal. from https://stat.unido.org/

Vazquez, M. L. (2017). Revisión del modelo de sustitución de importaciones: vigencia y algunas reconsideraciones. Economía Informa, 404(G), 4-17. doi: 10.1016/j. ecin.2017.05.008

Weber, M. ([1930] 2005). The Protestant Ethic and the Spirit of Capitalism. New York: Routledge.

World Bank. (2018a). World Bank Integrated Trade Solution. from https://wits.worldbank.org/

World Bank. (2018b). World Bank Open Data. from https://data.worldbank.org/

\section{Annex}

\section{Annex 1. 'Global Villages' Map}

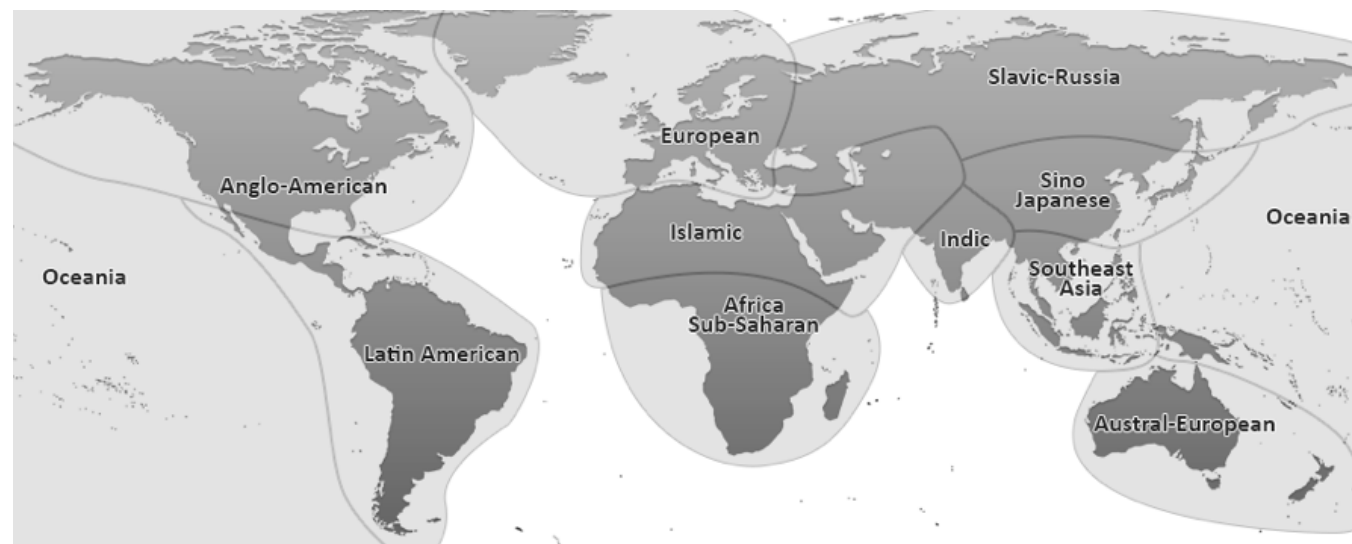




\section{Annex 2. Cultural Clusters ${ }^{12}$}

\begin{tabular}{|c|c|c|c|c|c|}
\hline LATIN AMERICAN & SINO & \multicolumn{2}{|c|}{ EUROPEAN } & SLAVIC & ISLAMIC \\
\hline Argentina & China & Andorra & Lithuania & Albania & Algeria \\
\hline Brazil & Hong Kong & Austria & Luxembourg & Armenia & Azerbaijan \\
\hline Chile & Japan & Belgium & Malta & Belarus & Bangladesh \\
\hline Costa Rica & Korea South & Belgium (French) & Netherlands & Bosnia & Cyprus \\
\hline Dominican Rep & SOUTH EAST ASIA & Belgium (Netherlands) & Norway & Bulgaria & Egypt \\
\hline Ecuador & Philippines & Denmark & Poland & Czech Rep & Iran \\
\hline El Salvador & Singapore & Estonia & Portugal & Croatia & Iraq \\
\hline Guatemala & Taiwan & Finland & Spain & Georgia & Jordan \\
\hline Jamaica & Thailand & France & Sweden & Macedonia Rep & Indonesia \\
\hline Mexico & Vietnam & Germany & Switzerland & Moldova & Malaysia \\
\hline Panama & AUSTRAL EUROPEAN & Greece & Switzerland (French) & Montenegro & Kyrgyz Rep \\
\hline Peru & Australia & Great Britain & Switzerland (German) & Romania & Morocco \\
\hline Suriname & New Zealand & Hungary & & Russian Fed. & Pakistan \\
\hline Trinidad and Tobago & ANGLO AMERICAN & Iceland & SINGLES & Serbia & Saudi Arabia \\
\hline $\begin{array}{l}\text { Uruguay } \\
\text { Venezuela }\end{array}$ & \begin{tabular}{|l} 
Canada \\
Canada (French)
\end{tabular} & $\begin{array}{l}\text { Ireland } \\
\text { Italy }\end{array}$ & \begin{tabular}{|l|} 
India \\
Israel
\end{tabular} & $\begin{array}{l}\text { Slovak Rep } \\
\text { Slovenia }\end{array}$ & Turkey \\
\hline COLOMBIA & U.S.A. & Latvia & South Africa & Ukraine & \\
\hline
\end{tabular}

12 Clusters were adjusted according to data availability. Trinidad and Tobago is included in the Latin American cluster because data for all analyzed factors (HCD, Export Composition, and Industrial Competitive Index) was available, while the available HCD database did not include Honduras, therefore excluded here. India, Israel, South Africa and Colombia are considered each as separate clusters. 